\title{
NGHIÊN CỨU ĐÁNH GIÁ KẾT QUẢ BƯớC ĐẦU PHẪU THUẬT TIM ÍT XÂM LẤN CÓ NỘI SOI HỖ TRỌ TẠI VIỆN TIM MẠCH, BỆNH VIỆN BẠCH MAI
}

\author{
Dương Đức Hùng*, Phạm Quốc Đạt*, Vuoong Hải Hà*, \\ Dương Thị Hoan*, Lê Đức Thắng*, Nguyễn Đức Nhã*, Phạm Thái Son*
}

\section{TÓM TẮT}

Tổng số 71 bệnh nhân $(\mathrm{BN})$ : 71,8\% là nữ giới; tuổi trung bình $41,8 \pm 11,20$. Phẫu thuật: Vá thông liên nhĩ: $22 \mathrm{BN}(30,9 \%)$; Sửa/thay van hai lá (VHL): $49 \mathrm{BN}(69,1 \%)$. Kỹ thuật mổ: tuần hoàn ngoài cơ thể ngoại vi: động mạch, tĩnh mạch đùi, tĩnh mạch cảnh trong phải. Mở ngực nhỏ 4-6cm, có nội soi hỗ trợ. Bảo vệ cơ tim bằng dung dịch máu ấm, xuôi dòng qua gốc động mạch chủ. cặp động mạch chủ bằng clamp ChiWood. Thành công về mặt kỹ thuật $100 \%$. Thời gian cặp chủ, chạy máy: nhóm VHL:64,0 \pm 15,3 phút/103,1 \pm 24,3 phút; TLN có cặp chủ :40,1 $\pm 20,53$ phút/69,9 $\pm 26,81$ phút; TLN không cặp chủ có thời gian chạy máy: $65,9 \pm 21,24$ phút. Diễn biến sau mổ: Thời gian thở máy (giờ)/hồi sức (ngày)/nằm viện (ngày) nhóm VHL, TLN lần lượt: $21,6 \pm 14,89 / 1,3 \pm$ $0,67 / 1,3 \pm 0,67$ và $15,3 \pm 3,17 / 15,3 \pm$ $3,17 / 15,3 \pm 3,17$. Biến chứng: Tỷ lệ tử vong: $0 \%$; loạn thần: $3 \mathrm{BN}(4,2 \%)$, chảy máu mổ lại: $1 \mathrm{BN}(1,4 \%)$. Lâm sàng và các chỉ số siêu âm cải thiện rõ rệt sau mổ. Phẫu thuật tim hở ít xâm lấn có nội soi hỗ trợ thu được kết quả tốt, cho thấy đây là phương pháp ít xâm lấn, an toàn, hiệu quả cho điều trị bệnh lý van hai lá và thông liên nhĩ.

Tù khóa: Phẫu thuật tim ít xâm lấn, bệnh viện Bạch Mai

\section{Evaluation of results of minimally invasive cardiac surgery with video assisted in Bach Mai hospital}

\section{SUMMARY}

A total of 71 patients, females $(71.8 \%)$ mean age was $41.8 \pm 11.2$ years. Surgery included: 22 cases close atrial septal defect and tricuspid valve plasty, 49 cases of mitral valve replacement +/- tricuspid valve plasty. Surgical techniques: peripheral perfution canulation; 4-6cm small right thoracotomy; MICS system installation; clamp aorta with Chiwood clamp, cardioplegia with warm blood and performing procedures with thoracoscopic instruments support. Technical success was $100 \%$. CPB time/aortic clamp time: Mitral valve group:64,0 \pm 15,3 mín/103,1 $\pm 24,3$ min ASD group with aortic clamp:40,1 $\pm 20,53 \mathrm{~min} / 69,9 \pm 26,81 \mathrm{~min}$;

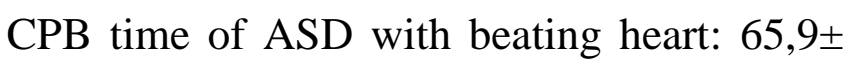
21,24 min.Postoperative outcomes: Mortality 0\%; Complications: Bleeding: 1 cases $(1,2 \%)$; Transient ischemic attack : 3 case (4.2\%); Postoperative echocardiographywith good results. MICS could be performed with good results at Bach Mai hospital and this ís a safe

\footnotetext{
* Đơn vị phẫu thuật tim mạch C8, Viện Tim mạch, BV Bạch Mai Ngưòi chịu trách nhiệm khoa học.TS. Dưong Đức Hùng Ngày nhận bài: 01/10/2017 - Ngày Cho Phép Đăng: 05/10/2017 Phản Biện Khoa học: PGS.TS. Đặng Ngoc Hùng GS.TS. Lê Ngọc Thành
} 
and effective procedure for treatment mitral valve disease and atrial septal defect.

Keywords: Open heart surgery minimally invasive, Minimally Invasive Cardiac Surgery (MICS), Bach Mai hospital.

\section{I. ĐẶT VẤN ĐỀ}

Phương pháp phẫu thuật tim ít xâm lấn là các kỹ thuật nhằm giảm thiểu chấn thương do phẫu thuật với việc sử dụng đường mổ nhỏ hơn so với đường mở xương ức thông thường. Hiện nay, phẫu thuật tim ít xâm lấn (minimally invasive cardiac surgery) đang là một cuộc cách mạng trong phẫu thuật tim trên thế giới.

Năm 1996, Carpentier và cộng sự đã thực hiện thành công đầu tiên ca sửa van hai lá (VHL) qua đường mở nhỏ ngực phải có nội soi hỗ trợ đã đánh dấu một bước quan trọng trong cuộc cách mạng của phẫu thuật ít xâm lấn trong phẫu thuật tim hở[1]. Trải qua hơn 10 năm phát triển, phẫu thuật tim ít xâm lấn, đặc biệt với nội soi hỗ trợ đã dần khẳng định vị trí, ngày càng trở thành phẫu thuật thường quy ở rất nhiều trung tâm tim mạch lớn trên thế giới với những kết quả đã được ghi nhận.Các nghiên cứu đều chỉ ra rằng đây là một phương pháp an toàn, giảm sang chấn, ít đau, ít chảy máu, giảm thời gian thở máy, hồi sức và nằm viện, tính thẩm mỹ cũng như giảm thiểu tỷ lệ nhiễm trùng vết mổ với tỷ lệ tử vong không có sự khác biệt so với phương pháp mở xương ức truyền thống[2-5].

Tại Việt Nam, phẫu thuật tim hở ít xâm lấn có nội soi hỗ trợ đã được thực hiện trong thời gian gần đây tại một số trung tâm phẫu thuật tim mạch[6]. Những kết quả ban đầu cho thấy phương pháp an toàn, khả thi, có thể triển khai thường quy với các bệnh lý về VHL hay thông liên nhĩ (TLN) thể thông thường. Viện tim mạch,bệnh viện Bạch mai đã bắt đầu ứng dụng kỹ thuật này trong phẫu thuật tim hở từ năm 2013. Tuy nhiên chưa có nghiên cứu nào đánh giá kết quả của phương pháp mổ này. Vì vậy chúng tôi thực hiện nghiên cứu này nhằm mục tiêu:

1. Nhận xét về quy trình kỹ thuật phẫu thuật tim hở it xâm lấn có nội soi hỗ trợ tại viện Tim mạch, bệnh viện Bạch Mai.

2. Đánh giá kết quả buớc đầu của phuoong pháp mổ tim hở it xâm lấn có nội soi hỗ trọ̆.

\section{II. ĐỐI TƯợNG VÀ PHƯƠNG PHÁP NGHIÊN CÚU}

\section{1. Đối tượng nghiên cứu}

Gồm tất cả các bệnh nhân có chỉ định và được phẫu thuật bằng kỹ thuật ít xâm lấn có nội soi hỗ trợ bao gồm:

- Phẫu thuật sửa/thay VHLđơn thuần hoặc kèm theo sửa van ba lá (VBL), lấy huyết khối, khâu loại trừ tiểu nhĩ trái (TNT).

- Phẫu thuật vá TLN.

Bệnh nhân không có chống chỉ định phẫu thuật đường ngực phải: mổ cũ, tia xạ, lồng ngực cấu trúc bất thường, không có bệnh mạch máu ngoại vi nặng.

Bệnh nhân và người nhà bệnh nhân đồng ý lựa chọn phương pháp phẫu thuật ít xâm lấn sau khi được giải thích về các phương pháp phẫu thuật và nguy co. 


\subsection{Phương pháp nghiên cứu}

\subsubsection{Thiết kế nghiên cứu}

Nghiên cứu mô tả tiến cứu

Cỡ mẫu: gồm tất cả các bệnh nhân được phẫu thuật ít xâm lấn từ 1/2016 đến 12/2016 tại đơn vị phẫu thuật tim mạch, viện tim mạch, bệnh viện Bạch Mai.

\subsubsection{Phương tiện và dụng cụ}

Chuẩn bị phương tiện và dụng cụ giống như một ca phẫu thuật tim hở thường quy, ngoài ra cần các dụng cụ chuyên dụng cho phẫu thuật ít xâm lấn nhu:Giàn nội soi, bộ dụng cụ phẫu thuật ít xâm lấn.Các ống thông thiết lập hệ thống tuần hoàn ngoài cơ thể ngoại vi. Máy chống rung tim với miếng chống rung dán ngoài.

\subsubsection{Quy trình phẫu thuật}

Gây mê, đặt nội khí quản, ven trung ương tĩnh mạch cảnh bên trái.

Tư thế bệnh nhân nằm nghiêng trái khoảng 30-40 độ, dán chống rung ngoài.

Mở ngực khoang liên sườn (KLS)IV đường nách trước $4-6 \mathrm{~cm}$. Camera vị trí KLS III đường nách trước. Heparin $3 \mathrm{mg} / \mathrm{kg}$. Thiết lập hệ thống tuần hoàn ngoài cơ thể ngoại vi qua động mạch, tĩnh mạch đùi và tĩnh mạch cảnh trong phải.

Mở màng tim cách thần kinh hoành ít nhất $3 \mathrm{~cm}$, khâu treo màng tim. Đặt dây thắt tĩnh mạch chủ trên, chủ dưới trong trường hợp cần mở nhĩ phải.

Trường hợp cần liệt tim. Đặt kim gốc ĐMC qua vết mổ.Clamp ĐMC bằng clamp
ChitWood qua KLS IV, đường nách giữa.Sử dụng dung dịch máu ấm.

Mở nhĩ phải trong trường hợp vá thông liên nhĩ hay sửa van ba lá.

Mở nhĩ trái theo đường kinh điển, trong trường hợp can thiệp van hai lá

Kiểm tra huyết khối nhĩ, tiểu nhĩ, khâu tiểu nhĩ nếu cần.

Thay/sửa van hai lá như thường quy.

Đóng các đường mở tim. Khâu điện cực và tăng cường chân kim gốc động mạch chủ trước khi tim đập lại. Thả cặp chủ, sốc điện nếu cần. Tim đập trở lại, tiếp tục duy trì tuần hoàn ngoài cơ thể để hỗ trợ tim.Kiểm tra cầm máu kỹ thành ngực và các đường khâu. Hạ dần lưu lượng rồi cai máy tuần hoàn ngoài cơ thể.

Đặt 2 dẫn lưu (màng phổi và màng tim). Đóng vết mổ.

\section{KẾT QUẢ}

Trong thời gian nghiên cứucó 71 bệnh nhân (BN) được mổ theo phương pháp ít xâm lấn có nội soi hỗ trợ, gồm $22 \mathrm{BN}$ TLN (30,9\%), $49 \mathrm{BN}$ sửa/thay VHL $(69,1 \%)$.

\section{1. Đặc điểm chung bệnh nhân}

Tổng số: $71 \mathrm{BN} ; 71,8 \%$ là nữ giới; tuổi trung bình 41,8 $\pm 11,20(\min 17-\max 57)$.

Tiền sử: Nhóm TLN không có tiền sử đặc biệt. Nhóm VHL: thấp tim:6BN (12,2\%); TBMN: 6BN (12,2\%); Viêm nội tâm mạc: $6 \mathrm{BN}(12,2 \%)$; Nong van cũ: 4 BN $(8,2 \%)$; đái tháo đường: $1 \mathrm{BN}(2,0 \%)$. Không có bệnh nhân có bệnh lý mạch ngoại vi. 
Bảng 3.1. Một số đặc điểm chung theo nhóm bệnh nhân

\begin{tabular}{|l|l|l|}
\hline & Vá thông liên nhĩ(N=22) & Sửa/thay van hai lá(N=49) \\
\hline NYHAtb & $1,45 \pm 0,51$ & $2,16 \pm 0,37$ \\
\hline Rung nhĩ & $0(0 \%)$ & $37(75,5 \%)$ \\
\hline EF (\%) & $66,8 \pm 6,52$ & $62,2 \pm 9,23$ \\
\hline
\end{tabular}

3.2. Đặc điểm tổn thương và kỹ thuật xử lý trong mổ

Đặc điểm thương tổn giải phẫu trong mổ

- Thông liên nhĩ: lỗ thứ phát: 18BN (81,8\%); thể xoang tĩnh mạch 4BN (18,2\%), kích thước trung bình: $32,1 \pm 3,87 \mathrm{~mm}$ ( $\min 24-\max 40)$.

- Van hai lá: tổn thương dạng thấp: $40 \mathrm{BN}(81,6 \%)$; thoái hóa: $7 \mathrm{BN}(14,2 \%)$; Viêm nội tâm mạc nhiễm khuẩn: $2 \mathrm{BN}(4,2 \%)$.

Bảng 3.2. Thời gian cặp động mạch chủ/chạy máy

\begin{tabular}{|l|l|l|l|}
\hline \multirow{2}{*}{} & \multicolumn{2}{|c|}{ Nhóm thông liên nhĩ } & \multirow{2}{*}{$\begin{array}{c}\text { Nhóm } \\
\text { sửa/thay VHL }\end{array}$} \\
\cline { 2 - 3 } & \multicolumn{1}{|c|}{ Nhóm cặp ĐMC } & Không cặp ĐMC & $\begin{array}{l}64,0 \pm 15,3 \\
\text { (min 34- max 102) }\end{array}$ \\
\hline $\begin{array}{l}\text { Thời gian kẹp ĐMC } \\
\text { phút) }\end{array}$ & $\begin{array}{l}40,1 \pm 20,53 \\
(\min 23-\max 87)\end{array}$ & 0 & $\begin{array}{l}103,1 \pm 24,3 \\
(\min 58-\max 165)\end{array}$ \\
\hline $\begin{array}{l}\text { Thời gian chạy máy } \\
\text { THNCT (phút) }\end{array}$ & $\begin{array}{l}69,9 \pm 26,81 \\
(\min 34-\max 124)\end{array}$ & $\begin{array}{l}65,9 \pm 21,24 \\
(\min 43-\max 114)\end{array}$ &
\end{tabular}

Bảng 3.3. Các kỹ thuật mổ sử dụng

\begin{tabular}{|l|c|c|}
\hline \multirow{2}{*}{\multicolumn{1}{|c|}{ Các kỹ thuật }} & \multicolumn{2}{|c|}{ Nhóm thông liên nhĩ (N=22) } \\
\cline { 2 - 3 } & Số lượng $(\mathrm{n})$ & Tỷ lệ (\%) \\
\hline Vá bằng miếng vá nhân tạo & 22 & $100 \%$ \\
\hline Sửa van hai lá kèm theo & 1 & $4,5 \%$ \\
\hline Sửa van ba lá kèm theo & 2 & $9,1 \%$ \\
\hline & \multicolumn{2}{|c|}{ Nhóm van hai lá (N=49) } \\
\hline Sửa van hai lá & 3 & $6,1 \%$ \\
\hline Thay van hai lá cơ học & 46 & $93,9 \%$ \\
\hline Khâu loại trừ tiểu nhĩ trái & 5 & $10,2 \%$ \\
\hline Sửa van ba lá kèm theo & 7 & $14,3 \%$ \\
\hline
\end{tabular}

Tất cả $\mathrm{BN}$ thay van đều được thay van bằng kỹ thuật khâu vắt. 


\subsection{Kết quả sau mổ}

Bảng 3.4. Thời gian điều trị sau mổ

\begin{tabular}{|l|l|l|}
\hline Thời gian điều trị & Nhóm TLN $(\mathbf{N}=22)$ & Nhóm VHL $(\mathbf{N}=49)$ \\
\hline Thời gian thở máy (giờ) & $\begin{array}{l}15,3 \pm 3,17 \\
(\min 4-\max 18)\end{array}$ & $\begin{array}{l}21,6 \pm 14,89 \\
(\min 12-\max 90)\end{array}$ \\
\hline Thời gian nằm hồi sức (ngày) & $\begin{array}{l}0,98 \pm 0,10 \\
(\min 0,5-\max 1)\end{array}$ & $\begin{array}{l}1,3 \pm 0,67 \\
(\min 1-\max 4)\end{array}$ \\
\hline Thời gian nằm viện (ngày) & $\begin{array}{l}6,9 \pm 1,02 \\
(\min 5-\max 9)\end{array}$ & $\begin{array}{l}8,4 \pm 1,76 \\
(\min 6-\max 14)\end{array}$ \\
\hline
\end{tabular}

Bảng 3.5. Các tai biến biến chứng trong và sau mổ

\begin{tabular}{|l|c|c|}
\hline Tai biến & Số lượng & Tỷ lệ (\%) \\
\hline Tử vong & 0 & 0 \\
\hline Thất bại kỹ thuật & 0 & 0 \\
\hline Loạn thần & 3 & $4,2 \%$ \\
\hline Tồn thương động mạch đùi & 1 & $1,4 \%$ \\
\hline Chảy máu phải mổ lại & 1 & $1,4 \%$ \\
\hline Viêm phổi & 1 & $1,4 \%$ \\
\hline Tràn khí màng phổi & 2 & $2,8 \%$ \\
\hline Nhiễm trùng vết trocart & 1 & $1,4 \%$ \\
\hline Nhiễm trùng vết mổ đùi & 0 & 0 \\
\hline Hở cạnh van, shunt tồn lưu & 0 & 0 \\
\hline
\end{tabular}

Tỷ lệ kháng sinh dụ̣ phòng: nhóm TLN 21 BN (95,5\%); nhóm VHL 38 BN (77,6\%).

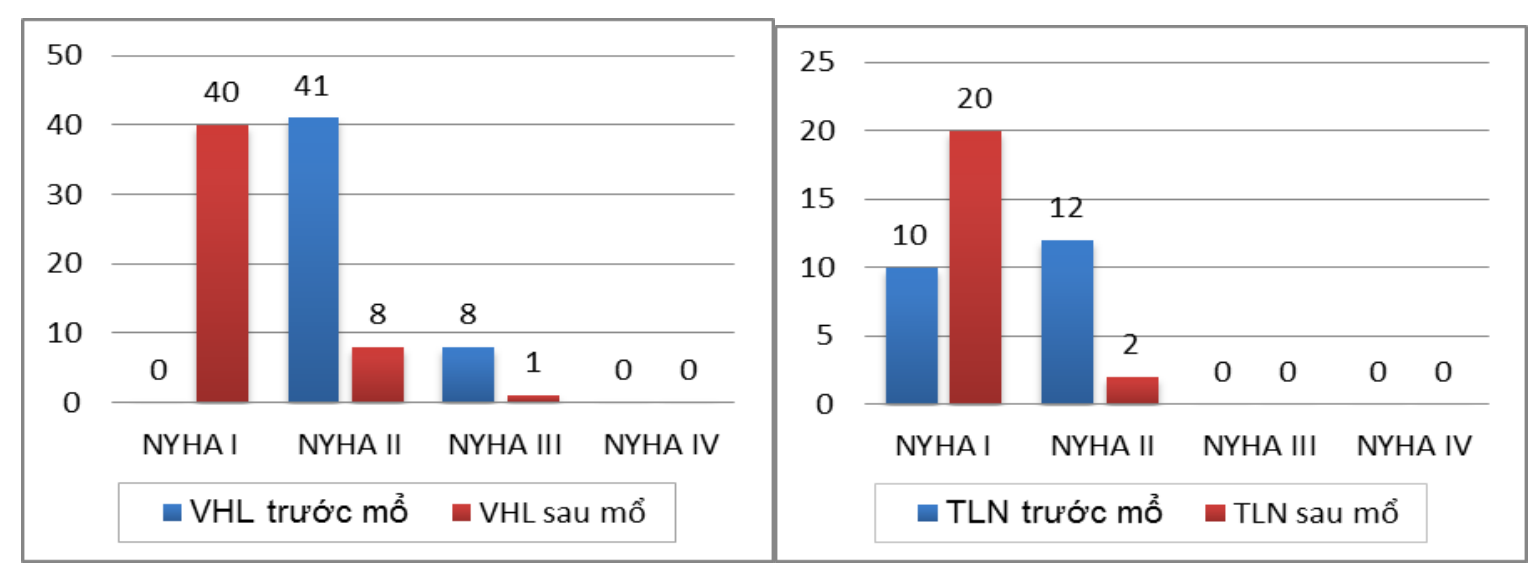

Biểu đồ 3.1. So sánh NYHA trước và sau mổ 
Sau mổ tỷ lệ bệnh nhân NYHA II, III, giảm rõ rệt so với trước mổ. Tỷ lệ NYHA II-III trước mổ/sau mổ van hai lá: $100 \%$ so với 18,4\%; Tỷ lệ NYHA II trước mổ/sau mổ thông liên nhĩ: $54,5 \%$ so với $9,1 \%$

Bảng 3.6. Thay đổi trên SÂ lúc ra viện so với trước mổ

\begin{tabular}{|l|l|l|l|}
\hline Các chỉ số SÂ tim & SÂ trước mổ & SÂ ra viện & p \\
\hline Nhóm thông liên nhĩ (N= 22) & $36,7 \pm 3,09$ & $24,6 \pm 3,91$ & $<0,05$ \\
\hline ĐK thất phải (mm) & $42,0 \pm 7,10$ & $29,1 \pm 4,69$ & $<0,05$ \\
\hline Áp lực ĐMP tâm thu (mmHg) & $66,8 \pm 6,52$ & $68,2 \pm 7,50$ & 0,23 \\
\hline EF (\%) & $51,2 \pm 7,87$ & $44,9 \pm 7,20$ & $<0,05$ \\
\hline Nhóm sửa/thay van hai lá & $42,1 \pm 8,97$ & $30,0 \pm 4,07$ & $<0,05$ \\
\hline ĐK thất trái tâm trương (mm) & $62,2 \pm 9,23$ & $59,7 \pm 7,61$ & 0,132 \\
\hline Áp lụ̣c ĐMP tâm thu (mmHg) & $17,5 \pm 5,85$ & $7,7 \pm 2,05$ & $<0,05$ \\
\hline EF (\%) & $8,6 \pm 5,50$ & $2,9 \pm 1,00$ & $<0,05$ \\
\hline $\begin{array}{l}\text { Chênh áp qua van } \\
\text { hai lá }\end{array}$ & Tâm thu & Trung bình &
\end{tabular}

\section{BÀN LUẬN}

4.1. Quy trình kỹ thuật mổ tim hở ít xâm lấn với nội soi hỗ trợ

Về vấn đề thông khí phổi: chúng tôi chọn giải pháp thông khíhai phổi giống như phẫu thuật tim hở thông thường. Với giải pháp thông khí hai phổi chúng tôi tránh được biến chứng nói khàn do nội khí quản hai nòng lớn đè vào dây thanh âm.

Thiết lập hệ thống tuần hoàn ngoài cơ thể ngoại vi:tất cả các bệnh nhân của chúng tôi đều thiết lập tuần hoàn ngoài cơ thể qua động mạch, tĩnh mạch đùi bằng kỹ thuật bộc lộ trực tiếp. Trường hợp lưu lượng không đủ và phẫu thuật thông liên nhĩ , van ba lá phải can thiệp vào nhĩ phải chúng tôi đặt ống thông tĩnh mạch chủ trên bằng phương pháp chọc qua da qua tĩnh mạch cảnh trong ở vị trí tĩnh mạch cảnh trong phải.

Với đường rạch da khoảng $2 \mathrm{~cm}$ ngay trên nếp lằn bẹn đảm bảo được mặt thẩm mỹ và cũng giảm thiểu việc cắt qua tổ chức bạch huyết dẫn đến dò bạch huyết sau mổ hay nhiễm trùng sau mổ. Trong nhóm bệnh nhân của chúng tôi không có bệnh nhân nào bị dò bạch huyết hay nhiễm trùng vết mổ đùi.

Bảo vệ cơ tim: Giải pháp bảo vệ cơ tim và kỹ thuật đặt ống thông trong bảo vệ cơ tim vẫn còn nhiều tranh cãi. Tuy nhiên có rất ít bằng chứng cho rằng việc bảo vệ cơ tim xuôi dòng, ngược dòng, ngắt quãng, liên tục, dung dịch tinh thể hay máu hoặc thậm chí để tim 
đập, rung tim trong quá trình mổ có sự khác biệt. Chúng tôi sử dụng bảo vệ cơ tim bằng dung dịch máu ấm, xuôi dòng qua gốc động mạch chủ bằng một kim động mạch chủ đặt qua vết mổ, nhắc lại sau mỗi 15-20 phút. Kimgốc động mạch chủ cũng được sử dụng để đuổi khí khi tim đập lại. Giải pháp không kẹp chủ để tim đập cũng được chúng tôi sử dụng trong phẫu thuật vá thông liên nhĩ. Kết quả không có bệnh nhân nào bị tai biến về thần kinh hay tắc mạch do khí.

Kỹ thuật thay van hai lá, sửa van hai lá:có 46 bệnh nhân $(93,9 \%)$ được thay van hai lá cơ học còn lại 3 bệnh nhân được sửa van $(6,1 \%)$. Do đa số bệnh nhân đều tổn thương do thấp tim, van tổn thương nặng nên không có khả năng sửa chữa phải thay thế. Có 3 bệnh nhân sửa van đều có tổn thương sa vùng $\mathrm{P} 2$, được sửa bằng kỹ thuật cắt tứ giác và đặt vòng van. Với các bệnh nhân thay van, $100 \%$ bệnh nhân được thay van bằng kỹ thuật khâu vắt. Với kỹ thuật này chúng tôi thường bắt đầu từ vị trí $6 \mathrm{~h}$ và kết thúc đường khâu ở vị trí $12 \mathrm{~h}$. Với chỉ một lần buộc chỉ là có thể cố định được van. Do vậy tiết kiệm được thời gian chạy máy cũng như cặp động mạch chủ.

Xử lý các thương tổn kèm theo bao gồm: khâu tiểu nhĩ trái: $5 \mathrm{BN}$ (10,2\%); loại bỏ tiểu nhĩ trái là một biện pháp rất có giá trị để tránh tái phát huyết khối sau mổ. Sửa van ba lá:7 BN (14,3\%). Việc tạo hình van ba lá sẽ giúp giảm bớt tình trạng suy tim phải sau mổ, cải thiện chất lượng cuộc sống cho bệnh nhân.

Kỹ thuật vá thông liên nhĩ: 100\% chúng tôi sử dụng miếng vá nhân tạo và dùng kỹ thuật khâu vắt giống như mổ mở bình thường.

Xử lý thương tổn kèm theo: có 2 bệnh nhân hở van ba lá nặng được sửa van ba lá bằng phương pháp đặt vòng van nhân tạo, có 1 bệnh nhân sửa van hai lá bằng vòng van nhân tạo.

\subsection{Kết quả phẫu thuật ít xâm lấn nội soi hỗ trọ̣}

Thời gian cặp động mạch chủ (ĐMC) và thời gian chạy máy THNCT

Nhóm TLN: Với nhóm cặp chủ chúng tôi có thời gian cặp ĐMC: 40,1 $\pm 20,53$ phút; thời gian chạy máy: $69,9 \pm 26,81$ phút; nhóm không cặp chủ có thời gian chạy máy $65,9 \pm$ 21,24 phút. Trong thời gian đầu triển khai mổ chúng tôi chọn giải pháp có cặp ĐMC để vá thông liên nhĩ dễ dàng hơn, tuy nhiên khi làm chủ kỹ thuật thì đa số các trường hợp chúng tôi đều chọn phương pháp không cặp chủ, do vậy tiết kiệm được thời gian đặt cũng như rút kim động mạch chủ. Kết quả là thời gian chạy máy của nhóm không cặp chủ ngắn hơn so với nhóm có cặp động mạch chủ.

Nhóm VHL: Thời gian cặp ĐMC, chạy máy THNCT lần lượt là $64,0 \pm 15,3$ phút, $103,1 \pm 24,3$ phút. Kết quả của chúng tôi ngắn hơn so với các nghiên cứu của như Aybek[7] (84 \pm 26 phút, $142 \pm 40$ phút), Reichenspurner[8] (78 \pm 65phút, $120 \pm 25$ phút), Mohr [2](69 \pm 26 phút, $127 \pm 49$ phút), Iribarne [9](84 \pm 2 phút, $140 \pm 3$ phút), Grossi[4] (92 \pm 3phút, $127 \pm 43$ phút).

Để có thể rút ngắn được thời gian cặp chủ cũng như thời gian chạy máy chúng tôi sử dụng một số cách tiếp cận như sau: 1. Lựa 
chọn bệnh nhân không quá nặng, chưa phẫu thuật lần nào; 2. Bộc lộ tim rõ ràng phẫu trường khô bằng cách đặt 2 ống thông tĩnh mạch hỗ trợ hút áp lực âm; 3. Sử dụng kỹ thuật khâu vắt trong thay VHL.

\section{Các biến chứng sau mổ}

Tỷ lệ tử vong: Trong nghiên cứu của chúng tôi, không có trường hợp nào tử vong tương tự với nghiên cứu của Felger [42] và Reichenspurner[8]. Tỷ lệ tử vong trong nghiên cứu của chúng tôi thấp hơn các tác giả Mishra [10](1,3\%), Iribarne [9](1,8\%), Aybek[7] (3,3\%), có thể giải thích bởi bệnh nhân của chúng tôi có độ tuổi trung bình trẻ hơn, ít các bệnh phối hợp kèm theo hơn do đó tiên lượng hồi sức sau phẫu thuật tốt hơn, giảm thiểu tỷ lệ tử vong.

Biến chứng thần kinh:Do sự giới hạn phẫu trường trong phẫu thuật VHL ít xâm lấn, đuổi khí khó khăn dẫn tới một tỷ lệ bệnh nhân gặp những biến chứng thần kinh. Trong nghiên cứu của Grossi và cộng sự, tỷ lệ tai biến thần kinh là 2,9\% (21/714 BN)[4], Davierwala và cộng sự $3,7 \%$ (128/3438 $\mathrm{BN})[11]$. Các nghiên cứu cũng tìm ra những nguy cơ cao gây nên biến chứng thần kinh gồm có: bệnh mạch máu ngoại vi, bệnh mạch máu não, xơ vữa động mạch chủ và nhấn mạnh rằng sử dụng tuần hoàn ngoài cơ thể, với bơm máu động mạch ngược dòng (đặt ống thông động mạch đùi) trong bệnh lý động mạch chủ là yếu tố nguy cơ cao nhất dẫn tới tai biến mạch não sau mổ.

Nghiên cứu của chúng tôi ghi nhận một tỷ lệ 4,2\% BN bị loạn thần (4/71 BN). Đa số BN xuất hiện triệu chứng ngày thứ nhất sau mổ, tất cả đều hồi phục và không để lại di chứng. Điều đặc biệt là chúng tôi không gặp trường hợp nào loạn thần ở nhóm thông liên nhĩ, kể cá nhóm không cặp chủ. Điều này cho thấy vá thông liên nhĩ không cặp chủ là một phương pháp an toàn.

Chảy máu sau mổ: Giảm tỷ lệ chảy máu và số lượng máu truyền sau mổ đã được xem như một lợi ích của phẫu thuật ít xâm lấn.Trong nghiên cứu của chúng tôi, có $1 \mathrm{BN}$ chảy máu cần mổ lại $(1,4 \%)$ do chảy máu từ vết mổ thành ngực.So sánh tỷ lệ phải mổ lại vì chảy máu với một số tác giả, kết quả của chúng tôi cao hơn nghiên cứu của Mishra[10], nhưng thấp hơn nghiên cứu của Mohr[2], Iribarne[9], Davierwala[11]. Theo các tác giả, nguyên chính chảy máu là từ thành ngực, cũng tương đồng với nghiên cứu của chúng tôi. Ngoài ra nghiên cứu của Aybek[7] còn ghi nhận 2 BN chảy máu mổ lại do tổn thương động mạch ngực trong, 1 chảy máu từ đường khâu nhĩ trái, 1 vỡ thất, $3 \mathrm{BN}$ chảy máu từ kim gốc động mạch chủ.

Nhiễm trùng sau mổ: Tỷ lệ nhiễm trùng vết mổ trong phẫu thuật VHL ít xâm lấn qua đường mở ngực thấp hơn so với đường giữa xương ức thông thường. Grossi và cộng sự [4] thông báo tỷ lệ nhiễm trùng vết mổ $0,9 \%$ so với 5,7\% trong phẫu thuật ít xâm lấn và phẫu thuật truyền thống, khác biệt có ý nghĩa thống kê $(\mathrm{p}=0,05)$. Tỷ lệ này tăng $1,8 \%$ và $7,7 \%$ ở những bệnh nhân cao tuổi $(\mathrm{p}=0,03)$. Tỷ lệ nhiễm trùng vết mổ ngực, đùi trong nghiên cứu của chúng tôi thấp hơnso với trung tâm khác trên thế giới. Có thể thấy thời gian mổ 
của chúng tôi thấp hơn nên thời gian phơi nhiễm thấp hơn. Với đường mở mạch ở đùi chúng tôi cũng mở nhỏ, hạn chế cắt vào các tổ chức bạch huyết nên cũng không gặp trường hợp nào bị tụ dịch hay dò bạch huyết ở đùi.

Về điều trị kháng sinh sau mổ:tỷ lệ chỉ cần sử dụng kháng sinh dự phòng của chúng tôi khá cao:với nhóm TLN: 95,5\%; nhóm VHL 77,6\%. Đây là một trong những ưu điểm của phương pháp mổ ít xâm lấn. Phẫu trường bé, tim ít bị phơi nhiễm ra môi trường hơn, bệnh nhân đỡ đau, rút ống sớm nên vận động sớm, tránh được các biến chứng do nằm lâu.

Biến chứng hô hấp: Nghiên cứu của chúng tôi ghi nhận có 2 trường hợp bị tràn khí màng phổi $(2,8 \%)$, các trường hợp này do trong quá trình mổ làm tổn thương nhu mô phổi dẫn đến bị xì khí ra khoang màng phổi khi thờ máy áp lực dương, tuy nhiên với các trường hợp này chúng tôi chỉ cần lưu dẫn lưu màng phổi lâu hơn là hết; không trường hợp nào phải mổ lại, tỷ lệ viêm phổi là $1,8 \%$, suy hô hấp $0 \%$.

Biến chứng liên quan đến quá trình thiết lập tuần hoàn ngoài cơ thể: Trong nghiên cứu của chúng tôi có 1 trường hợp tổn thương động mạch đùi đoạn ngã ba, do ống thông lớn hơn so với kích thước của động mạch đùi, sau khi khâu phục hồi lại động mạch đùi chúng tôi thấy có hiện tượng hẹp động mạch đùi do vậy chúng tôi tiến hành giải phóng 2 đầu động mạch, cắt đoạn hẹp và tạo hình lại ngã ba động mạch đùi. Chúng tôi không gặp trường hợp nào tổn thương tĩnh mạch đùi hay lóc tách động mạch chủ.
Thất bại kỹ thuật: Trong nghiên cứu của chúng tôi tất cả $71 \mathrm{BN}$ đều được thực hiện thành công kỹ thuật, không có trường hợp nào phải mở rộng đường mở ngực, trong mổ không có $\mathrm{BN}$ nào phải chuyển mở xương ức.

Nghiên cứu của Morh có $4 \mathrm{BN}$ phải chuyển mở xương ức, 3 trường hợp lóc động mạch chủ cấp (lóc ngược); 1 vỡ thất trái 4 giờ sau mổ thay VHL trên $\mathrm{BN}$ vôi hoá nặng vòng VHL và tổ chức dưới van. Kinh nghiệm của Mohr một lần nữa cho thấy việc chọn lựa đối tượng của phẫu thuật thay VHL ít xâm lấn là hết sức quan trọng, bệnh nhân xơ vữa mạch, có bệnh mạch máu ngoại vi, vôi hoá VHL nặng không phù hợp với phương pháp này[2].

\section{Biến chứng hở cạnh van, shunt tồn lưu:} Đánh giá kết quả sớm sau phẫu thuật, nghiên cứu của chúng tôi không có trường hợp nào kẹt van, không có bệnh nhân nào hở cạnh van và thông liên nhĩ tồn lưu.Tỷ lệ hở cạnh van của Aybek và cộng sự là $0,4 \%$, Mohr 3,9\%, Reichenspurner là $0,8 \%$. Tỷ lệ này ở nghiên một số nghiên cứu trong nước áp dụng phẫu thuật thay VHL truyền thống như Đặng Hanh Đệ 2,2\%, Nguyễn Xuân Thành là 13\%.Điều này cho thấy phẫu thuật thay VHL ít xâm lấn an toàn, với tỷ lệ hở cạnh van thấp. Nhóm thông liên nhĩ chúng tôi cũng không gặp trường hợp nào còn shunt tồn lưu.

\section{Thời gian hồi phục sau mổ}

Trong số các lợi ích của phẫu thuật ít xâm lấn, giảm đau, sớm hồi phục và trở về hoạt động bình thường là những ưu điểm lớn nhất của phẫu thuật. So sánh với các nghiên cứu phẫu thuật thay VHL của Nguyễn Xuân 
Thành, Nông Hữu Thọ theo phương pháp kinh điển, thời gian thở máy trong nghiên cứu chúng tôi có thời gian tương đương. Tuy nhiên, thời gian hồi sức được rút ngắn lại. Kết quả trên có thể được giải thích với phương pháp mới mức độ mất máu ít hơn, ít xâm lấn hơn phương pháp truyền thống. Do đó bệnh nhân sau mổ đỡ đau hơn, có thể ngồi dậy tập thở sớm hơn.

Thời gian nằm viện trong nghiên cứu chúng tôi là $8,4 \pm 1,76$, tương đương với các nghiên cứu khác.

Một số thay đổi trên lâm sàng và siêu âm tim sau phẫu thuật

NYHA:Nhóm thông liên nhĩ: chỉ còn 2 bệnh nhân NYHA II $(9,1 \%)$ cải thiện hẳn so với trước mổNYHA II $(54,5 \%)$. Nhóm van hai lá: chỉ còn $18,4 \%$ bệnh nhân NYHA II-III; so với trước mổ NYHA II-III (100\%).

Các chỉ số siêu âm: kích thước thất phải, thất trái, áp lực động mạch phổi để cải thiện rõ rệt sau mổ và có ý nghĩa thống kê so với trước mổ.

Chênh áp qua van hai lá:Chênh áp qua van trung bình, tối đa sau mổ lần lượt là $2,9 \pm 1,0 \mathrm{mmHg} ; 7,7 \pm 2,05 \mathrm{mmHg}$, giảm đáng kể so với trước phẫu thuật có ý nghĩa thống kê. Chênh áp qua van giảm là một trong những yếu tố đánh giá tình trạng hoạt động tốt của van nhân tạo.

\section{KẾT LUẬN}

Phẫu thuật tim hở ít xâm lấn có nội soi hỗ trợ được triển khai với quy trình hợp lý tại đơn vị phẫu thuật tim mạch, viện tim mạch, bệnh viên Bạch Mai. Kết quả cho thấy đây là phương pháp an toàn, hiệu quả trong điều trị bệnh lý van hai lá và thông liên nhĩ.

\section{TÀI LIỆU THAM KHẢO}

1. Carpentier, A., et al., [Open heart operation under videosurgery and minithoracotomy. First case (mitral valvuloplasty) operated with success]. C R Acad Sci III, 1996. 319(3): p. 219-23.

2. Mohr, F.W., et al., Minimally invasive port-access mitral valve surgery. J Thorac Cardiovasc Surg, 1998. 115(3): p. 567-74; discussion 574-6.

3. Chitwood, W.R., Jr., Minimally invasive mitral valve surgery: introduction. Semin Thorac Cardiovasc Surg, 1999. 11(3): p. 192-3.

4. Grossi, E.A., et al., Minimally invasive mitral valve surgery: a 6-year experience with 714 patients. Ann Thorac Surg, 2002. 74(3): p. 660-3; discussion 663-4.

5. McClure, R.S., et al., One thousand minimally invasive mitral valve operations: early outcomes, late outcomes, and echocardiographic follow-up. J Thorac Cardiovasc Surg, 2013. 145(5): p. 1199-206.

6. Nguyễn Công Hựu and Lê Ngọc Thành, Phẫu thuật tim hở ít xâm lấn với nội soi hỗ trợ tại Trung tâm Tim mạch bệnh viện E: Những bước đi ban đầu và triển vọng. Tạp chí Y học Việt Nam 2014. 1(414): p. 37-40.

7. Aybek, T., et al., Two hundred forty minimally invasive mitral operations through right minithoracotomy. Ann Thorac Surg, 2006. 81(5): p. 1618-24. 
8. Reichenspurner, H., et al., Video and discussion 1477-8.

robotic-assisted minimally invasive mitral valve surgery: a comparison of the PortAccess and transthoracic clamp techniques. Ann Thorac Surg, 2005. 79(2): p. 485-90; discussion 490-1.

9. Iribarne, A., et al., Minimally invasive versus sternotomy approach for mitral valve surgery: a propensity analysis. Ann Thorac Surg, 2010. 90(5): p. 1471-7;

10. Mishra, Y.K., et al., Port-access approach for cardiac surgical procedures: our experience in 776 patients. Indian Heart J, 2005. 57(6): p. 688-93.

11. Davierwala, P.M., et al., Minimally invasive mitral valve surgery: "The Leipzig experience". Ann Cardiothorac Surg, 2013. 2(6): p. 744-50. 